\title{
Sphingosine-1-Phosphate and Its Effect on Glucose Deprivation/Glucose Reload Stress: From Gene Expression to Neuronal Survival
}

\author{
Kinga Czubowicz • Magdalena Cieślik • Joanna Pyszko • \\ Joanna B. Strosznajder • Robert P. Strosznajder
}

Received: 8 April 2014 / Accepted: 8 July 2014 /Published online: 24 July 2014

(C) The Author(s) 2014. This article is published with open access at Springerlink.com

\begin{abstract}
Sphingosine kinase-1 (Sphk1-1, EC 2.7.1.91) is a regulator of pro-survival signalling, and its alterations have been observed in Alzheimer's disease, brain ischemia and other neurological disorders. In this study we addressed the question whether Sphk1 and its product, sphingosine-1phosphate (S1P), play a significant role in glucose deprivation (GD)/glucose reload (GR) stress in hippocampal neuronal cells (HT22). It was found that GD $(6 \mathrm{~h})$ followed by $24 \mathrm{~h}$ of GR evoked enhancement of the free radical level and neuronal HT22 cell death. Moreover, the significantly stronger gene expression for the pro-apoptotic Bax protein and down-regulation of the anti-apoptotic $\mathrm{Bcl}-2$ and $\mathrm{Bcl}-\mathrm{X}_{\mathrm{L}}$ proteins were observed. Concomitantly, this stress up-regulated: gene expression, protein level and activity of Sphk1. Exogenous S1P at $1 \mu \mathrm{M}$ concentration and the other agonists of the S1P1 receptor (SEW 2871 and P-FTY720) enhanced HT22 cell viability affected by GD/GR stress. This mechanism is mediated by S1P receptor(s) signalling and by the activation of gene expression for Bcl-2 and $\mathrm{Bcl}-\mathrm{X}_{\mathrm{L}}$. Summarising, our data suggest that sphingolipid metabolism may play an important role in the early events that take place in neuronal cell survival/death under GD/GR stress. Our data demonstrate that exogenous S1P, through the activation of specific receptors $\mathrm{S} 1 \mathrm{P} 1$ and S1P3 signalling pathways,
\end{abstract}

K. Czubowicz and M. Cieślik equally contributed to this study.

K. Czubowicz $\cdot$ R. P. Strosznajder $(\bowtie)$

Laboratory of Preclinical Research and Environmental Agents, Department of Neurosurgery, Mossakowski Medical Research

Centre, Polish Academy of Sciences, 5 Pawińskiego Street,

02-106 Warsaw, Poland

e-mail: rstrosznajder@imdik.pan.pl

M. Cieślik · J. Pyszko · J. B. Strosznajder

Department of Cellular Signaling, Mossakowski Medical Research

Centre, Polish Academy of Sciences, 5 Pawińskiego Street,

02-106 Warsaw, Poland regulates the gene expression for anti-apoptotic proteins and enhances neuronal cell survival affected by GD/GR stress.

Keywords Gucose deprivation · Sphingolipids · HT22 · $\mathrm{S} 1 \mathrm{P} \cdot$ Sphingosine kinase $1 \cdot \mathrm{Bcl}-2$ proteins

\section{Introduction}

Homeostasis of blood and cellular glucose is very important for the functioning of the central nervous system (CNS). Moderate hypoglycemia impairs neuronal functions, but severe hypoglycemia causes the death of vulnerable cells [1-3]. Despite intense efforts in research, the mechanism of neuronal cell death evoked by glucose deprivation (GD) followed by glucose reload (GR) is not yet fully understood. Previous data indicated the important role of excitotoxicity, but several other molecular events have also been suggested. It was observed that hypoglycemia induces a several-fold increase in glutamate and aspartate concentrations in the brain extracellular space [4]. Adenosine, which may reduce neuronal activity, can also increase during hypoglycemia [5, 6]. In addition, $\mathrm{a} \mathrm{Ca}^{2+}$ and $\mathrm{Zn}^{2+}$ influx, production of reactive oxygen (ROS) and nitrogen (RNS) species and mitochondrial failure have been described to be associated with hypoglycemic neuronal damage [7, 8].

Studies on the regulation of cell survival and death presented recently focused on the important role of bioactive sphingolipids in these processes. Many data have shown the signalling functions of two sphingolipids, ceramide and sphingosine-1-phosphate (S1P). Numerous studies demonstrated that level of ceramide is enhanced by a variety of cell stressors. It was reported to increase along with brain aging, ischemia and in neurodegenerative disorders [9-12]. A high level of ceramides can be responsible for cell growth arrest and apoptosis [13, 14]. However, S1P may promote cell survival and proliferation $[15,16]$. The balance between these 
two lipids (ceramide/S1P), which has been called the "sphingolipid-rheostat", is controlled by sphingosine kinases (Sphk) $[16,17]$. There are two isoforms of sphingosine kinases, Sphk1 and Sphk2, whose activities can be a crucial determinant of cell fate in stress responses.

S1P is implicated in both extracellular and intracellularmediated signalling. S1P synthesized in the cell by sphingosine kinases is released, via the $\mathrm{ABC}$ family of transporters from the cell and is able to act in an autocrine or paracrine manner [18, 19]. The intracellular actions of S1P have been recently identified [20-24], for example nuclear S1P synthesized by sphingosine kinase 2 binds to and inhibits HDAC1 and HDAC2. Their inhibition by S1P prevents histone deacetylation and enhanced transcription of the genes encoding the cyclin-dependent kinase inhibitor p21 and the transcriptional regulator c-fos [20]. Also, intracellular S1P generated by sphingosine kinase 1 was shown to be necessary for TRAF2 E3 ubiquitin ligase activity, which is essential for TNF-mediated events [21].

The majority of S1P biological effects are known to be mediated by the activation of five specific $G$ protein-coupled receptors (S1PR1-5) located on the cell surface. The S1P signalling through these receptors causes the activation of different downstream targets including: the Ras/ERK pathway to promote proliferation, the PI3K/Akt signalling to prevent apoptosis and the PI3K/Rac pathway involved with cytoskeletal rearrangement $[24,25]$.

Production of ROS can differently modulate Sphk1 and Sphk2 activity, depending on the severity of oxidative damage and the type of stress (ischemia, hypoxia and amyloid beta toxicity) [26-28]. Enhancement of Sphk1 activity at an early stage of stress signalling has a pro-survival effect by producing S1P and decreasing the ceramide concentration [29]. Sphk1/S1P can regulate cell viability and death by modulating the level of the Bcl-2 protein family [30, 31]. Until today, nothing is known about the role of Sphk1/S1P in GD/GR stress in hippocampal neuronal cells. The in vivo studies have indicated that hypoglycemic neuronal death is pronounced in hippocampal CA1, in the subiculum and dentate granule cell layer [32].

In our study we used mouse immortalised hippocampal neuronal cells (HT22) which had been already very well described [33] and widely applied in a large number of studies. The aim of this study was to examine the role of S1P in neuronal cell death evoked by GD/GR stress.

\section{Experimental Procedures}

\section{Cell Culture}

The studies were carried out using the mouse immortalised hippocampal nerve cell line HT22, which is a subclone of
HT4. HT4 cells were immortalised from primary mouse hippocampal neurons using a temperature-sensitive small virus$40 \mathrm{~T}$ antigen $[34,35]$. These cells retain the characteristics of differentiated neurons. HT22 cells were obtained from Professor David Schubert, Salk Institute, La Jolla, CA, USA. This cell line does not possess active ionotropic glutamate receptors and was very well described by Sagara and Schubert [33]. In accordance with this publication [33] HT22 cells express functional group I metabotropic glutamate receptors (mGluR1 and mGluR5). We recently used it extensively for different types of studies [36]. HT22 cells were cultured in 75$\mathrm{cm}^{2}$ flasks in DMEM supplemented with $10 \%$-heatinactivated fetal bovine serum (FBS), $1 \%$ penicillin/ streptomycin $(50 \mathrm{U} / \mathrm{ml})$ and $2 \mathrm{mM}$ glutamine. Cells were maintained at $37{ }^{\circ} \mathrm{C}$ in a humidified incubator containing $5 \% \mathrm{CO}_{2}$. The HT22 cells were used for experiments between five and ten passage numbers. We kept HT22 cells at no greater than $50 \%$ confluence. HT22 cells were seeded onto 96-well plate at a density of $2 \times 10^{3}$ cells per well in $100 \mu$ of medium. HT22 cells were seeded at $3 \times 10^{5}$ cells/ $10-\mathrm{mm}$ tissue culture dish.

\section{Glucose Deprivation/Glucose Reload}

Equal cell numbers were seeded into 48 -well or 96-well $0.1 \%$ polyethyleneimine coated plates. After $24 \mathrm{~h}$ the cells were rinsed two times with phosphate-buffered saline (PBS) and treated with low-serum (2\% FBS) glucosefree medium (Gibco, Invitrogen). GD was terminated after $6 \mathrm{~h}$ by exchanging the glucose-free medium to low-serum (2\% FBS) Dulbecco's modified Eagle medium (DMEM) supplemented with $25 \mathrm{mM}$ glucose. The extent of cell death was assessed after a $24 \mathrm{~h}$ GR period by using MTT assay. S1P $(1 \mu \mathrm{M})$ was added concomitantly with the initiation of GD. The cells were incubated with S1P $(1 \mu \mathrm{M})$ under GD conditions and also during the recovery period. Osmolarity of the medium used in this study was measured by using the Osmomat 030 - Gonotec. Osmolarity determined in the glucose-free medium in either the absence and presence of $25 \mathrm{mM}$ mannitol indicated small changes in osmolarity in the HT22 cells.

\section{Cell Viability Analysis}

Mitochondrial function and cellular viability were evaluated using 2-(4,5-dimethylthiazol-2-yl)-2,5-diphenyltetrazolium bromide (MTT). After $6 \mathrm{~h} \mathrm{GD/24} \mathrm{hGR} \mathrm{incubation} \mathrm{with} \mathrm{the}$ appropriate compounds, MTT $(2.5 \mathrm{mg} / \mathrm{ml})$ was added to all of the wells. The cells were incubated at $37^{\circ} \mathrm{C}$ for $2 \mathrm{~h}$. Then the cells were lysed in DMSO and spectrophotometric measurement was performed at $595 \mathrm{~nm}$. 


\section{Determination of Free Radicals Using DCF Probe}

ROS production in HT22 cells was assessed by using the $2^{\prime}, 7^{\prime}$ dichlorodihydrofluorescein diacetate (H2DCF-DA) probe $[37,38]$. Cell media was changed after $6 \mathrm{~h} \mathrm{GD/24} \mathrm{h}$ GR to Hanks' buffer and incubation was continued in the presence of $10 \mu \mathrm{M} \mathrm{H} 2 \mathrm{DCF}-\mathrm{DA}$ for $50 \mathrm{~min}$ at $37^{\circ} \mathrm{C}$. Then fluorescence (excitation $\left[\lambda_{\mathrm{ex}}\right], 485 \mathrm{~nm}$; emission $\left[\lambda_{\mathrm{em}}\right], 535 \mathrm{~nm}$ ) was quantified.

\section{Determination of Gene Expression}

Cells were washed twice with ice-cold PBS, scraped from the culture dish and centrifuged shortly ( $3 \mathrm{~min}, 1,000 \times \mathrm{g}$ ). RNA was isolated from the cell pellet by using TRI reagent according to the manufacturer's protocol (Sigma, St. Louis, MO, USA). Digestion of DNA contamination was performed by using DNase I according to the manufacturer's protocol (Sigma). RNA quantity and quality were controlled by spectrophotometric analysis and gel electrophoresis. Reverse transcription was performed by using a High Capacity cDNA Reverse Transcription Kit according to the manufacturer's protocol (Applied Biosystems, Foster City, CA, USA). Quantitative real time PCR was performed by using the following pre-developed TaqMan Gene Expression Assays
(Applied Biosystems): Bcl-2-Mm00477631_m1, Bcl211Mm00437783_m1, Bax-Mm00432051_m1, Sphk1Mn00448841_g1, Actb-Mm00607939_s 1 on an ABI PRISM 7500 apparatus according to the manufacturer's instructions. Actin (Actb) was selected and used in all of the studies as a reference gene. The level of mRNA was calculated by $\Delta \Delta C_{\mathrm{t}}$ method.

Immunochemical Determination of Protein Level (Western Blot)

After protein measurement according to Lowry, the homogenate of the HT22 cells was mixed with a $5 \times$ Laemmli sample buffer and denatured for $5 \mathrm{~min}$ at $95{ }^{\circ} \mathrm{C}$. Then, $40 \mu \mathrm{g}$ of protein was loaded per lane on $10 \%$ acrylamide gels and examined by SDS-PAGE. The proteins were transferred onto PVDF membranes at $100 \mathrm{~V}$. Membranes were incubated in $5 \%$ dry milk in TBS with Tween 20 (TBS-T) for $1 \mathrm{~h}$ and exposed overnight to the following antibodies: anti-Sphk1 (1:250, from Cell Signaling) and anti-GAPDH (1:4,000, from Sigma Aldrich). After treatment for $1 \mathrm{~h}$ with the corresponding horseradish peroxidase-coupled secondary antibodies (anti-rabbit from Sigma-Aldrich), the protein bands were detected by ECL reagent (ThermoScientific).
Fig. 1 Effect of GD/GR on HT22 cell viability (a), ROS generation (b) and gene expression of pro- and antiapoptotic Bcl-2 proteins (c). Data represent mean values \pm SEM for four separate experiments with four to six replications (a) and for three separate experiments with three replications $(\mathbf{b}, \mathbf{c})$. $* * * p<0.001$ versus control $[c]$ HT22 cells by Student's $t$-test $(\mathbf{a}, \mathbf{b}),{ }^{* * *} p<0.001,{ }^{*} p<00.01$ versus control [c] HT22 cells by one-way ANOVA followed by the Newman-Keuls test (c)
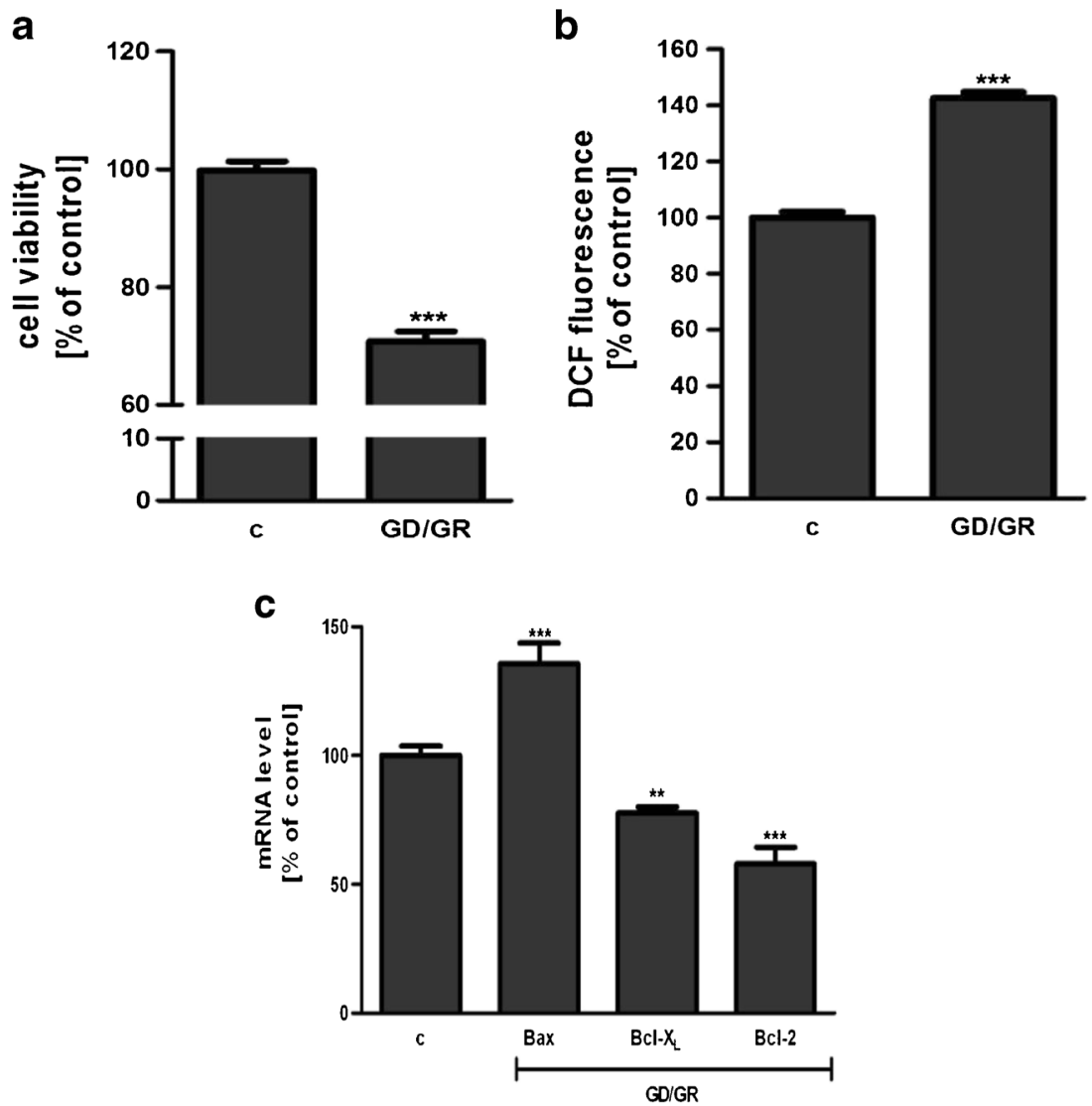


\section{Measurement of Sphk Activity}

Sphk activity assay was performed according to a previous report [23]. After $24 \mathrm{~h}$ incubation, the cells were washed with iced PBS and lysed by a freeze-thaw cycle in $50 \mathrm{mM}$ HEPES, $\mathrm{pH} 7.4,10 \mathrm{mM} \mathrm{KCl}, 15 \mathrm{mM} \mathrm{MgCl}_{2}, 0.1 \%$ Triton X-100, $20 \%$ glycerol, $2 \mathrm{mM}$ orthovanadate, $2 \mathrm{mM}$ dithiothreitol, $10 \mathrm{mM} \mathrm{NaF}, 1 \mathrm{mM}$ deoxypyridoxine, and EDTA-free complete protease inhibitor (Roche Applied Science). Lysates were cleared by centrifugation at $15,000 \mathrm{rpm}$ for $5 \mathrm{~min}$. The lysates and NBD-Sphingosine (10 $\mu \mathrm{M}$ final; Avanti Polar Lipids) were mixed in a reaction buffer (50 mM HEPES, $\mathrm{pH} 7.4,15 \mathrm{mM} \mathrm{MgCl}_{2}, 0.5 \mathrm{mM} \mathrm{KCl}, 10 \%$ glycerol and $2 \mathrm{mM}$ ATP) and incubated for $30 \mathrm{~min}$ at $30^{\circ} \mathrm{C}$. The reactions were stopped by the addition of an equal amount of $1 \mathrm{M}$ potassium phosphate, $\mathrm{pH} 8.5$, followed by an addition of 2.5-fold chloroform/methanol (2:1), and then centrifuged at $15,000 \mathrm{rpm}$ for $1 \mathrm{~min}$. Only the reactant NBD-S1P, but not the substrate NBD-Sphingosine, was collected in the alkaline aqueous phase. The fluorescence value was measured $\left(\lambda_{\mathrm{ex}}=\right.$ $485 \mathrm{~nm}, \lambda_{\mathrm{e}} \mathrm{m}=538 \mathrm{~nm}$ ) after the aqueous phase was combined with an equal amount of dimethylformamide [39].

\section{Determination of Apoptosis}

Apoptosis was determined by Hoechst 33342 fluorescent staining. The cells were examined under a fluorescence microscope (Olympus BX51, Japan) and photographed with a digital camera (Olympus DP70, Japan). Cells with typical apoptotic nuclear morphology (nuclear shrinkage, condensation) were identified and counted. The results were expressed as percentages of apoptotic cells in the whole cell population.
Fig. 2 Sphingosine kinase activity, gene expression and protein level in hippocampal neuronal cells subjected to GD/ GR stress. Data represent the mean value \pm SEM for three separate experiments with three replications; ${ }^{*} p<0.05$ versus control $[c]$ HT22 cells by Student's $t$-test $(\mathbf{a}, \mathbf{c})$. The absolute value of Sphk1 activity in control HT22 cells is 2655 [AU]. The absolute value of Sphk1 activity in GD/GR treated HT22 cells is 3044 [AU]. Data represent the mean value \pm SEM for three separate experiments normalised against GAPDH, $* * p<0.01$ versus control $[c]$ HT2 2 cells by Student's $t$-test (b)
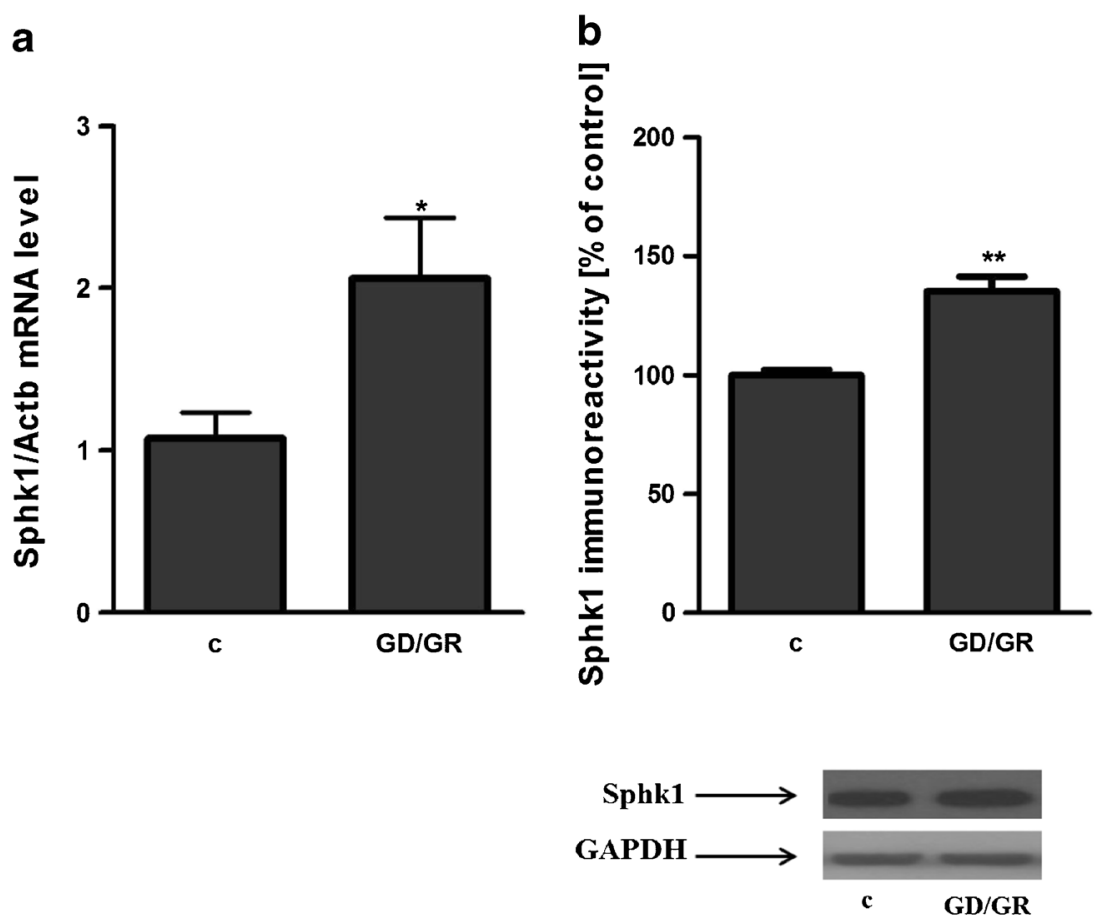

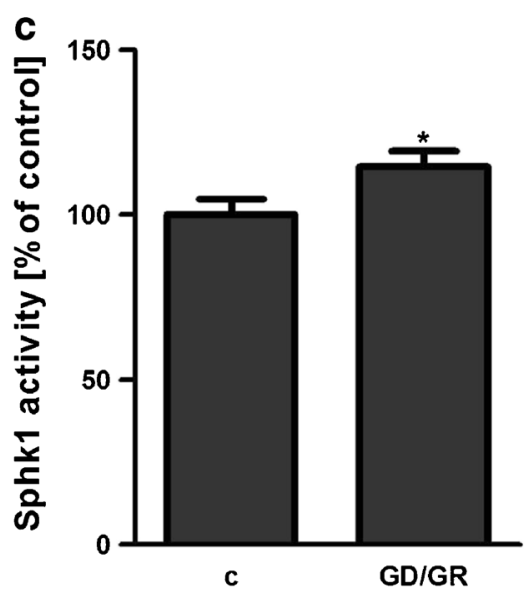




\section{Statistical Analysis}

The results were expressed as mean values \pm SEM. Differences between means were analysed using Student's $t$-test or oneway ANOVA followed by the Newman-Keuls test. Values of $p<0.05, p<0.01$ and $p<0.001$ were considered statistically significant.

\section{Results}

GD (6 h) followed by GR ( $24 \mathrm{~h})$ decreased the viability of HT22 cells by about $30 \%$. The effect of osmotic changes on these cells' survival was negligible. Our study presented that GD/GR leads to: significant cell death, enhancement of the free radical level and changes in the gene expressions of proand anti-apoptotic Bcl-2 proteins (Fig. 1a,b,c). Gene expression of the Hrk protein was observed at a very low level and was not altered by GD/GR (data not shown). GD/GR stress enhanced the gene expression, protein level and activity of Sphk1 (Fig. 2a,b,c). We also observed that exogenously added S1P significantly suppressed oxidative stress and increased HT22 cell survival affected by GD/GR (Fig. 3a,b). Microscopic examination of cell nuclei stained with DNAbinding fluorochrome Hoechst 33342 showed that HT22 cells exposed to GD/GR presented typical apoptotic morphology. The protective effect of S1P was seen in this fluorescence microscope study. This bioactive lipid significantly decreased death signalling evoked by GD/GR and the amount of apoptotic cells (Fig. 3c). Exogenous S1P at a concentration of $1 \mu \mathrm{M}$ significantly enhanced the expression of Bcl-2 and Bcl$\mathrm{X}_{\mathrm{L}}$, both anti-apoptotic proteins suppressed by GD/GR. However, S1P did not alter GD/GR-evoked changes of Bax (Fig. 4a,b,c). Finally, we investigated whether the S1P effect is receptor-mediated. Using S1P receptor agonists, i.e., S1P, SEW 2871 (a specific agonist for S1P1) and P-FTY720 (an agonist for S1P1, S1P3, S1P4, S1P5), we demonstrated that the neuroprotective effect of S1P is mediated by activation of these receptors (Fig. 5a). These results were confirmed by
Fig. 3 Effect of sphingosine-1phosphate on HT22 cell viability (a) and ROS generation (b) after exposure to GD/GR. Data represent the mean value \pm SEM for four separate experiments with four to six replications (a) and for three separate experiments with three replications (b).

$* * * p<0.001$ versus control [c] HT22 cells, ${ }^{\# \#} p<0.001$ versus GD/GR-treated cells by one-way ANOVA followed by the

Newman-Keuls test. Apoptosis induced by $\mathrm{GD} / \mathrm{GR}$ and the protective effect of S1P in HT22 cells (c). The number of apoptotic cells was counted. Data represent the mean value \pm SEM for three separate experiments with three replications, $* * * p<0.001$ versus control $[c]$ HT22 cells, $\#$ \#\# $p<0.001$ versus GD/GRtreated cells by one-way ANOVA followed by the Newman-Keuls test. The arrows indicate nuclei with typical apoptotic features
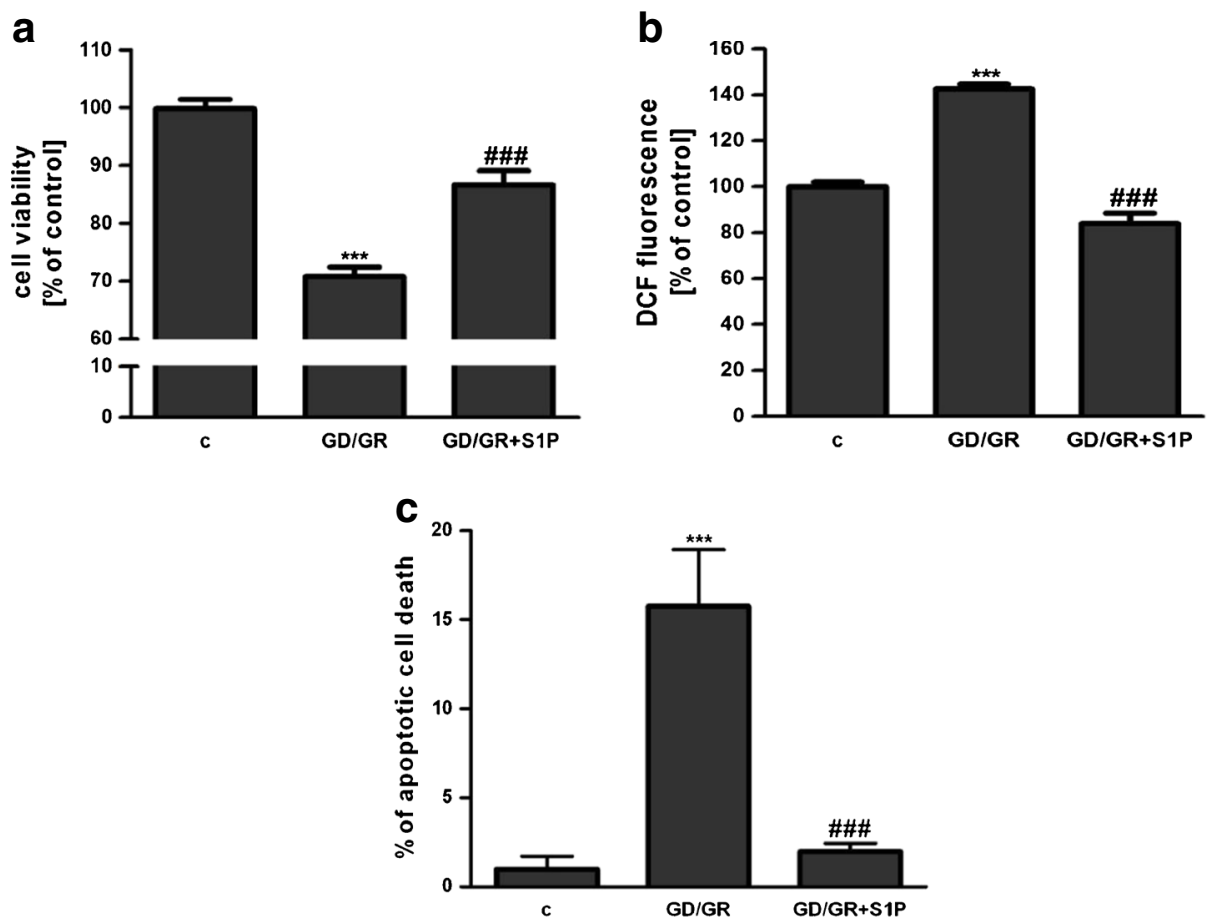

control

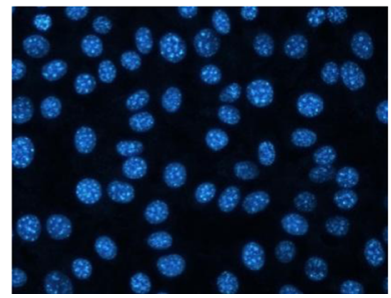

GD/GR

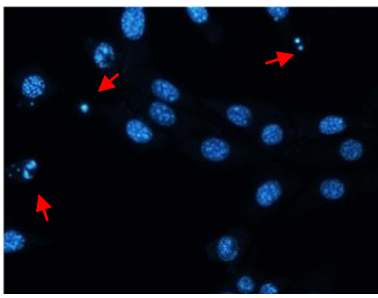

GD/GR+S1P

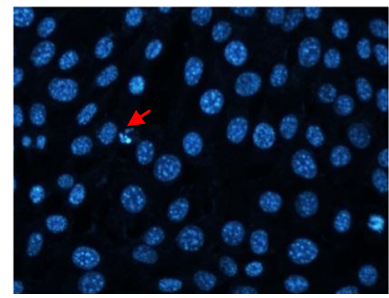


Fig. 4 Effect of GD/GR and S1P on the expression of $\mathrm{Bcl}-2$ (a), $\mathrm{Bcl}-\mathrm{X}_{\mathrm{L}}(\mathbf{b})$ and $\mathrm{Bax}(\mathbf{c})$ genes in HT22 cells. Data represent the mean value \pm SEM for three separate experiments with three replications, ${ }^{*} p<0.05,{ }^{* *} p<0.01$, $* * * p<0.001$ versus control [c] HT22 cells, ${ }^{*} p<0.05$, $p<0.001$ versus GD/GRtreated cells by one-way ANOVA followed by the Newman-Keuls test
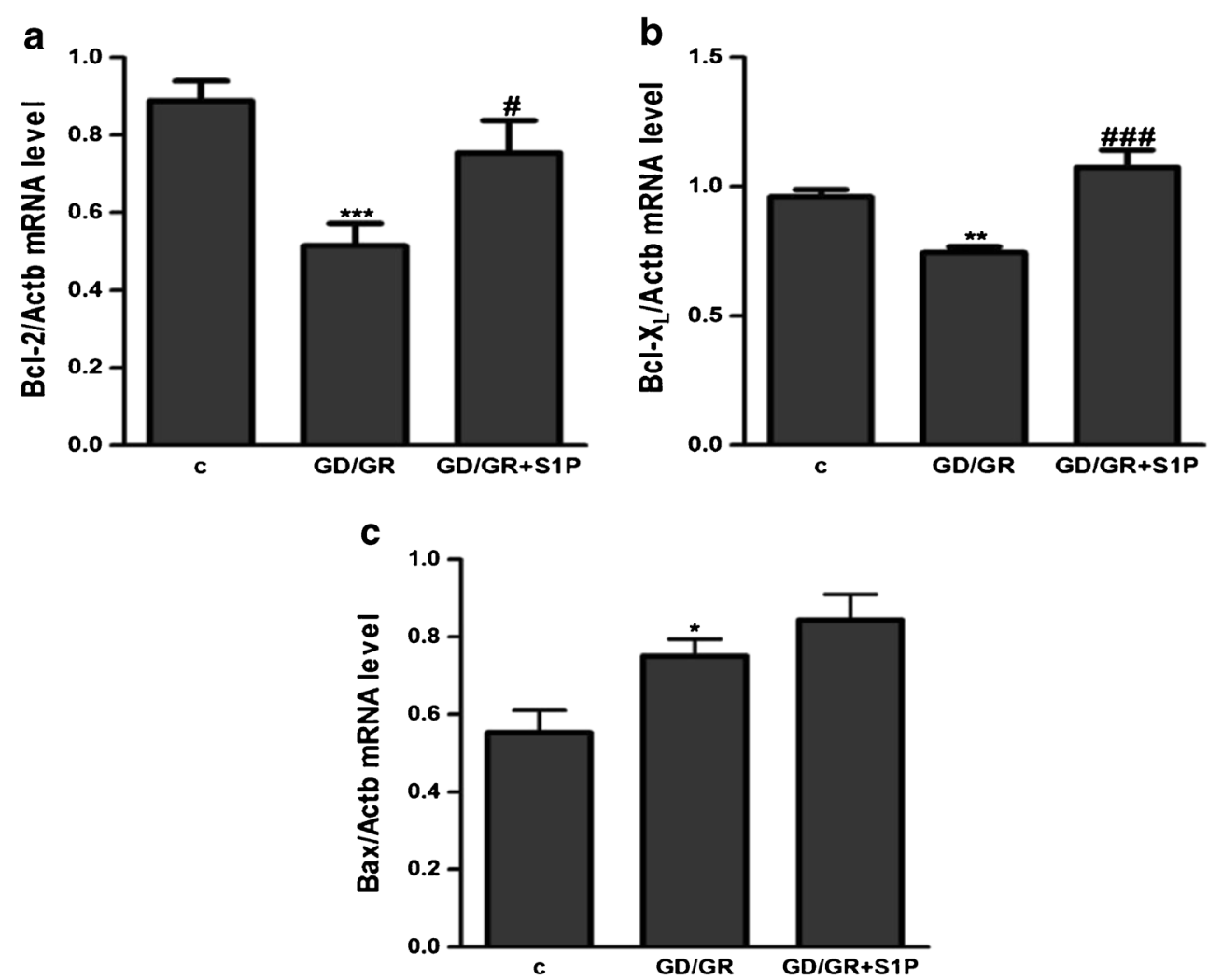

using antagonists for S1P1 and S1P3 (VPC23019) and the specific antagonist for S1P1 (W123). Cell survival analysis indicated that both compounds abolished the protective effect of S1P on HT22 cells (Fig. 5b). Gene expression analysis demonstrated that the mRNA level of S1P3 under GD/GR stress was significantly increased and that the mRNA level of S1P1 was not changed (Fig. 5c). Based on these results we propose that the neuroprotective effect of S1P is mainly dependent on $\mathrm{S} 1 \mathrm{P} 1$ and $\mathrm{S} 1 \mathrm{P} 3$ receptor stimulation.

\section{Discussion}

Although there are growing evidences that S1P receptor signalling may be neuroprotective in $\mathrm{AD}$, brain injury, ischemia and other neurological disorders [40-44], there is limited data about its involvement in GD/GR stress. In this study, we used an in vitro model of metabolic-oxidative stress evoked by GD followed by GR, which is observed in the pathological conditions as mentioned above. GD/GR leads to a significant enhancement of free radical concentrations and HT22 hippocampal neuronal cell death. These experimental conditions enhance gene expression for the pro-apoptotic protein Bax and concomitantly decrease expression for Bcl-2 and Bcl- $\mathrm{X}_{\mathrm{L}}$. Our study indicated for the first time, that the expression of Sphk1, the enzyme involved in pro-survival signalling [45, 46], was significantly increased. However, endogenous synthesis of S1P was not able to protect cells against death. Our study indicated the neuroprotective effect of exogenously applied S1P at a concentration of $1 \mu \mathrm{M}$ on death signalling in HT22 cell exposed to GD/GR stress. A higher concentration of S1P (10 and $30 \mu \mathrm{M}$ ) induced cell death from about $50 \%$ to $80 \%$, respectively (data not shown), probably through its degradation to sphingosine and ceramide. S1P, the product of Sphk1/2 activity, is a bioactive lipid mediator that promotes cell survival, proliferation, migration and angiogenesis. Disturbances in gene expression for Sphk1/Sphk2 and sphingosine-1-phosphate receptor 1 (S1P1) were observed in the animal experimental model of cerebral ischemia [47]. Spiegel and Milstien observed that the S1P analogue (PFTY720) reduced neuronal injury, possibly via S1P1 activation [47]. S1P may be also implicated in the neuroprotective effect in acute brain and spinal cord injury with regard to mitochondrial dysfunction and the oxidative stress mechanism [48]. The other in vitro experiments demonstrated that S1P inhibits apoptosis in response to oxidative stress induced by $\mathrm{H}_{2} \mathrm{O}_{2}$ [49]. It was observed that this antiapoptotic effect of S1P is mediated through PI3K/Akt signalling and is regulated through receptors S1P1 and S1P3. The protective effect of S1P was abolished after treatment with VPC23019, an antagonist of S1P1 and S1P3 receptors, W146, an antagonist of S1P1 receptors, and CAY10444, an antagonist of S1P3 receptors. According to our data the neuroprotective effect of S1P is also mediated by activation of receptors S1P1 and S1P3 in GD/GR toxicity. 
Fig. 5 Effect of S1P analogue P-FTY720, S1P1 receptor agonist SEW2871 (a) and S1P receptor $(1,3)$ antagonists (VPC23019 and W123) on HT22 cell viability (b), $* * * p<0.001$ versus control [c] HT22 cells, ${ }^{\#} p<0.05,{ }^{\# \# \#} p<0.001$ versus GD/GR-treated cells, $\$ \$ p<0.01$ versus S1P-pretreated and GD/GR-treated cells by oneway ANOVA followed by the Newman-Keuls test. Effect of GD/GR and S1P on the expression of S1P1 and S1P3 (c). Data represent the mean value \pm S.E.M for three separate experiments with three replications, ${ }^{* *} p<0.001$ versus control $[c]$ HT22 cells by Student's $t$-test
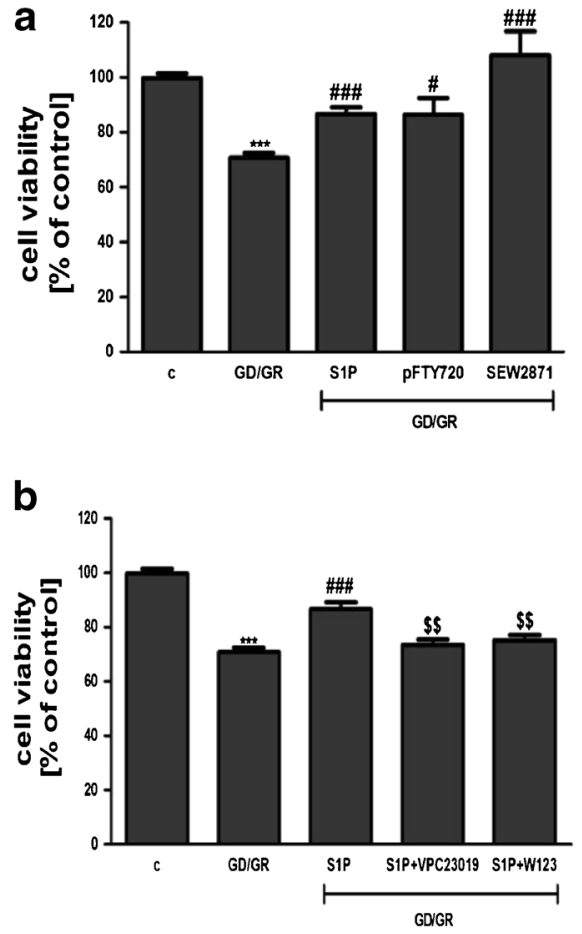
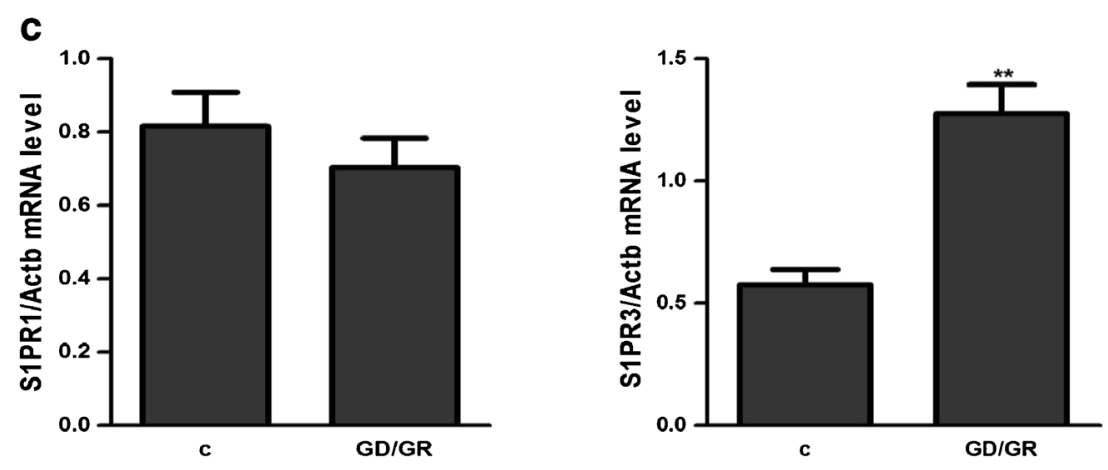

The S1P analogue P-FTY720 and the specific agonist of S1P1 (SEW2871) enhanced cell viability under GD/GR stress. It was also reported that mitochondria are involved in neuroprotective effect of S1P in oxygen-glucose deprivation model [50]. The data obtained by Agudo-López et al. [50] pointed out that S1P treatment significantly reduces both necrosis and apoptosis in the in vitro model of ischemia. The protection mecha nism involved stabilisation of the mitochondrial membrane potential, reduced calcium loading and decreased sensitivity to $\mathrm{mPTP}$ opening. Our data suggest that the protective mechanism of S1P is dependent on Bcl-2 proteins, which control a critical step in commitment to apoptosis by regulating permeabilisation of the mitochondrial outer membrane [51]. In our study, S1P regulated pro-survival signalling by enhancing expression of Bcl-2 and $\mathrm{Bcl}-\mathrm{X}_{\mathrm{L}}$; both anti-apoptotic proteins suppressed by GD/GR. Consequently S1P may lead to the stabilization of mitochondrial membrane potential and reduce the ROS production. Anti-apoptotic Bcl-2 family members $\left(\mathrm{Bcl}-2, \mathrm{Bcl}-\mathrm{X}_{\mathrm{L}}\right)$ have a well-described role in scaffolding the Bcl-2 homology (BH3) domain of proapoptotic Bcl-2-family members, thereby neutralising their pro-apoptotic activity [52]. According to some other studies, exogenous S1P regulate the expression of pro apoptotic and anti apoptotic proteins. It has been observed that S1P increases the expression of anti apoptotic Bcl-2 [53-55] and Mcl1 [56] as well as down-regulates the pro apoptotic proteins Bad and Bax [55, 57-59]. Overexpression of Sphk1 upregulates $\mathrm{Bcl}-2$ and down-regulates B-cell lymphoma 2 interacting mediator of cell death (Bim) [30, 31]. Similarly, overexpression of Sphk1 inhibits the activation of caspase 3, cytochrome $c$ and SMAC/Diablo release from mitochondria through the modulation of $\mathrm{Bim}, \mathrm{Bcl} \mathrm{X}_{\mathrm{L}}$ and Mcll in chronic myeloid leukaemia cells [29]. There are also evidences that Bcl-2 overexpression may stimulate Sphk1 expression and activity in human melanoma cells [60]. Our data indicate that stimulating effect of S1P on the expression of anti-apoptotic $\mathrm{Bcl}-2$ proteins can be an important protective mechanism against $\mathrm{GD} / \mathrm{GR}$ stress. 
Acknowledgments The studies were supported by NCN Grant 5870/B/PO1/2011/40 and by MRC statutory budget theme No. 1.

Open Access This article is distributed under the terms of the Creative Commons Attribution License which permits any use, distribution, and reproduction in any medium, provided the original author(s) and the source are credited.

\section{References}

1. Auer RN (1986) Progress review: hypoglycemic brain damage. Stroke 17:699-708

2. Auer RN (2004) Hypoglycemic brain damage. Forensic Sci Int 146: $105-110$

3. Suh SW, Gum ET, Hamby AM, Chan PH, Swanson RA (2007) Hypoglycemic neuronal death is triggered by glucose reperfusion and activation of neuronal NADPH oxidase. J Clin Invest 117:910-918

4. Wieloch T (1985) Hypoglycemia-induced neuronal damage prevented by an $N$-methyl-D-aspartate antagonist. Science 230: 681-683

5. Fowler JC (1993) Glucose deprivation results in a lactate preventable increase in adenosine and depression of synaptic transmission in rat hippocampal slices. J Neurochem 60:572-576

6. Zhu PJ, Krnjević K (1993) Adenosine release is a major cause of failure of synaptic transmission during hypoglycaemia in rat hippocampal slices. Neurosci Lett 155:128-131

7. Páramo B, Hernández-Fonseca K, Estrada-Sánchez AM, Jiménez N, Hernández-Cruz A, Massieu L (2010) Pathways involved in the generation of reactive oxygen and nitrogen species during glucose deprivation and its role on the death of cultured hippocampal neurons. Neuroscience 167:1057-1069

8. Suh SW, Garnier P, Aoyama K, Chen Y, Swanson RA (2004) Zinc release contributes to hypoglycemia-induced neuronal death. Neurobiol Dis 16:538-545

9. Tian HP, Qiu TZ, Zhao J, Li LX, Guo J (2009) Sphingomyelinaseinduced ceramide production stimulate calcium-independent JNK and PP2A activation following cerebral ischemia. Brain Inj 23: $1073-1080$

10. He X, Huang Y, Li B, Gong CX, Schuchman EH (2010) Deregulation of sphingolipid metabolism in Alzheimer's disease. Neurobiol Aging 31:398-408

11. Filippov V, Song MA, Zhang K, Vinters HV, Tung S, Kirsch WM, Yang J, Duerksen-Hughes PJ (2012) Increased ceramide in brains with Alzheimer's and other neurodegenerative diseases. J Alzheimers Dis 29:537-547

12. Couttas TA, Kain N, Daniels B, Lim XY, Shepherd C, Kril J, Pickford R, Li H, Garner B, Don AS (2014) Loss of the neuroprotective factor Sphingosine 1-phosphate early in Alzheimer's disease pathogenesis. Acta Neuropathol Commun 2:9

13. Tirodkar TS, Voelkel-Johnson C (2012) Sphingolipids in apoptosis. Exp Oncol 34:231-242

14. Mullen TD, Obeid LM (2012) Ceramide and apoptosis: exploring the enigmatic connections between sphingolipid metabolism and programmed cell death. Anticancer Agents Med Chem 12:340-363

15. Hannun YA, Obeid LM (2008) Principles of bioactive lipid signalling: lessons from sphingolipids. Nat Rev Mol Cell Biol 9:139-150

16. Van Brocklyn JR, Williams JB (2012) The control of the balance between ceramide and sphingosine-1-phosphate by sphingosine kinase: oxidative stress and the seesaw of cell survival and death. Comp Biochem Physiol B Biochem Mol Biol 163:26-36

17. Cuvillier O, Pirianov G, Kleuser B, Vanek PG, Coso OA, Gutkind S, Spiegel S (1996) Suppression of ceramide-mediated programmed cell death by sphingosine-1-phosphate. Nature 381:800-803
18. Blaho VA, Hla T (2014) An update on the biology of sphingosine 1-phosphate receptors. J Lipid Res

19. Takabe K1, Spiegel S (2014) Export of sphingosine-1-phosphate and cancer progression. J Lipid Res

20. Hait NC, Allegood J, Maceyka M, Strub GM, Harikumar KB, Singh SK, Luo C, Marmorstein R, Kordula T, Milstien S, Spiegel S (2009) Regulation of histone acetylation in the nucleus by sphingosine-1phosphate. Science 325:1254-1257

21. Alvarez SE, Harikumar KB, Hait NC, Allegood J, Strub GM, Kim EY, Maceyka M, Jiang H, Luo C, Kordula T, Milstien S, Spiegel S (2010) Sphingosine-1-phosphate is a missing cofactor for the E3 ubiquitin ligase TRAF2. Nature 465:1084-1088

22. Ader I, Brizuela L, Bouquerel P, Malavaud B, Cuvillier O (2008) Sphingosine kinase 1: a new modulator of hypoxia inducible factor 1alpha during hypoxia in human cancer cells. Cancer Res 68:8635-8642

23. Takasugi N, Sasaki T, Suzuki K, Osawa S, Isshiki H, Hori Y, Shimada N, Higo T, Yokoshima S, Fukuyama T, Lee VM, Trojanowski JQ, Tomita T, Iwatsubo T (2011) BACE1 activity is modulated by cell-associated sphingosine-1-phosphate. J Neurosci 31:6850-6857

24. Maceyka M, Harikumar KB, Milstien S, Spiegel S (2012) Sphingosine-1-phosphate signaling and its role in disease. Trends Cell Biol 22:50-60

25. Obinata H, Hla T (2012) Sphingosine 1-phosphate in coagulation and inflammation. Semin Immunopathol 34:73-91

26. Jin ZQ, Goetzl EJ, Karliner JS (2004) Sphingosine kinase activation mediates ischemic preconditioning in murine heart. Circulation 110: 1980-1989

27. Gomez-Brouchet A, Pchejetski D, Brizuela L, Garcia V, Altié MF, Maddelein ML, Delisle MB, Cuvillier O (2007) Critical role for sphingosine kinase-1 in regulating survival of neuroblastoma cells exposed to amyloid-beta peptide. Mol Pharmacol 72:341-349

28. Huwiler A, Kotelevets N, Xin C, Pastukhov O, Pfeilschifter J, Zangemeister-Wittke U (2011) Loss of sphingosine kinase-1 in carcinoma cells increases formation of reactive oxygen species and sensitivity to doxorubicin-induced DNA damage. Br J Pharmacol 162:532-543

29. Bonhoure E, Lauret A, Barnes DJ, Martin C, Malavaud B, Kohama T, Melo JV, Cuvillier O (2008) Sphingosine kinase-1 is a downstream regulator of imatinib-induced apoptosis in chronic myeloid leukemia cells. Leukemia 22:971-979

30. Guan H, Song L, Cai J, Huang Y, Wu J, Yuan J, Li J, Li M (2011) Sphingosine kinase 1 regulates the $\mathrm{Akt} / \mathrm{FOXO} \mathrm{a} / \mathrm{Bim}$ pathway and contributes to apoptosis resistance in glioma cells. PLoS One 6: e19946

31. Limaye V, Li X, Hahn C, Xia P, Berndt MC, Vadas MA, Gamble JR (2005) Sphingosine kinase-1 enhances endothelial cell survival through a PECAM-1-dependent activation of PI-3K/Akt and regulation of Bcl-2 family members. Blood 105:3169-3177

32. Suh SW, Hamby AM, Swanson RA (2007) Hypoglycemia, brain energetics, and hypoglycemic neuronal death. Glia 55:1280-1286

33. Sagara Y, Schubert D (1998) The activation of metabotropic glutamate receptors protects nerve cells from oxidative stress. J Neurosci 18:6662-6671

34. Frederiksen K, Jat PS, Valtz N, Levy D, McKay R (1988) Immortalization of precursor cells from the mammalian CNS. Neuron 1:439-448

35. Lendahl U, McKay RD (1990) The use of cell lines in neurobiology. Trends Neurosci 13:132-137

36. Cieslik M, Pyszko J, Strosznajder JB (2013) Docosahexaenoic acid and tetracyclines as promising neuroprotective compounds with poly(ADP-ribose) polymerase inhibitory activities for oxidative/ genotoxic stress treatment. Neurochem Int 62:626-636

37. Royall JA, Ischiropoulos H (1993) Evaluation of 2',7'dichlorofluorescin and dihydrorhodamine 123 as fluorescent 
probes for intracellular $\mathrm{H}_{2} \mathrm{O}_{2}$ in cultured endothelial cells. Arch Biochem Biophys 302:348-355

38. Zehendner CM, Librizzi L, Hedrich J, Bauer NM, Angamo EA, de Curtis M, Luhmann HJ (2013) Moderate hypoxia followed by reoxygenation results in blood-brain barrier breakdown via oxidative stress-dependent tight-junction protein disruption. PLoS One 8(12): e82823

39. Billich A, Ettmayer P (2004) Fluorescence-based assay of sphingosine kinases. Anal Biochem 326:114-119

40. Asle-Rousta M, Kolahdooz Z, Oryan S, Ahmadiani A, Dargahi L (2013) FTY720 (fingolimod) attenuates beta-amyloid peptide (A 342 )-induced impairment of spatial learning and memory in rats. J Mol Neurosci 50:524-532

41. Rolland WB 2nd, Manaenko A, Lekic T, Hasegawa Y, Ostrowski R, Tang J, Zhang JH (2011) FTY720 is neuroprotective and improves functional outcomes after intracerebral hemorrhage in mice. Acta Neurochir Suppl 111:213-217

42. Hasegawa Y, Suzuki H, Altay O, Rolland W, Zhang JH (2013) Role of the sphingosine metabolism pathway on neurons against experimental cerebral ischemia in rats. Transl Stroke Res 4:524-532

43. Hemmati F, Dargahi L, Nasoohi S, Omidbakhsh R, Mohamed Z, Chik Z, Naidu M, Ahmadiani A (2013) Neurorestorative effect of FTY720 in a rat model of Alzheimer's disease: comparison with memantine. Behav Brain Res 252:415-421

44. Takasugi N, Sasaki T, Ebinuma I, Osawa S, Isshiki H, Takeo K, Tomita T, Iwatsubo T (2013) FTY720/fingolimod, a sphingosine analogue, reduces amyloid- $\beta$ production in neurons. PLoS One 8: e64050

45. Pitson SM (2011) Regulation of sphingosine kinase and sphingolipid signaling. Trends Biochem Sci 36:97-107

46. Meng H, Yuan Y, Lee VM (2011) Loss of sphingosine kinase 1/S1P signaling impairs cell growth and survival of neurons and progenitor cells in the developing sensory ganglia. PLoS One 6:e27150

47. Spiegel S, Milstien S (2003) Sphingosine-1-phosphate: an enigmatic signalling lipid. Nat Rev Mol Cell Biol 4:397-407

48. Singh IN, Hall ED (2008) Multifaceted roles of sphingosine-1phosphate: how does this bioactive sphingolipid fit with acute neurological injury? J Neurosci Res 86:1419-1433

49. Nakahara T, Iwase A, Nakamura T, Kondo M, Bayasula, Kobayashi H, Takikawa S, Manabe S, Goto M, Kotani T, Kikkawa F (2012)
Sphingosine-1-phosphate inhibits $\mathrm{H}_{2} \mathrm{O}_{2}$-induced granulosa cell apoptosis via the PI3K/Akt signaling pathway. Fertil Steril 98:1001-8.e1

50. Agudo-López A, Miguel BG, Fernández I, Martínez AM (2010) Involvement of mitochondria on neuroprotective effect of sphingosine-1-phosphate in cell death in an in vitro model of brain ischemia. Neurosci Lett 470:130-133

51. Shamas-Din A, Kale J, Leber B, Andrews DW (2013) Mechanisms of action of Bcl-2 family proteins. Cold Spring Harb Perspect Biol 5: a008714

52. Monaco G, Vervliet T, Akl H, Bultynck G (2013) The selective BH4domain biology of Bcl-2-family members: IP3Rs and beyond. Cell Mol Life Sci 70:1171-1183

53. Potteck H, Nieuwenhuis B, Lüth A, van der Giet M, Kleuser B (2010) Phosphorylation of the immunomodulator FTY720 inhibits programmed cell death of fibroblasts via the S1P3 receptor subtype and Bcl-2 activation. Cell Physiol Biochem 26:67-78

54. Sauer B, Gonska H, Manggau M, Kim DS, Schraut C, SchäferKorting M, Kleuser B (2005) Sphingosine 1-phosphate is involved in cytoprotective actions of calcitriol in human fibroblasts and enhances the intracellular Bcl-2/Bax rheostat. Pharmazie 60:298-304

55. Czubowicz K, Strosznajder R (2014) Ceramide in the molecular mechanisms of neuronal cell death. The role of sphingosine-1phosphate. Mol Neurobiol. doi:10.1007/s12035-013-8606-4

56. Li QF, Wu CT, Guo Q, Wang H, Wang LS (2008) Sphingosine 1phosphate induces Mcl-1 upregulation and protects multiple myeloma cells against apoptosis. Biochem Biophys Res Commun 371:159-162

57. Goetzl EJ, Kong Y, Mei B (1999) Lysophosphatidic acid and sphingosine 1-phosphate protection of T cells from apoptosis in association with suppression of Bax. J Immunol 162:2049-2056

58. Betito S, Cuvillier O (2006) Regulation by sphingosine 1-phosphate of Bax and Bad activities during apoptosis in a MEK-dependent manner. Biochem Biophys Res Commun 340:1273-1277

59. Pyszko J, Strosznajder JB (2014) Sphingosine kinase 1 and sphingosine-1-phosphate in oxidative stress evoked by 1-methyl-4phenylpyridinium (MPP+) in human dopaminergic neuronal cells. Mol Neurobiol. doi:10.1007/s12035-013-8622-4

60. Bektas M, Jolly PS, Müller C, Eberle J, Spiegel S, Geilen CC (2005) Sphingosine kinase activity counteracts ceramide-mediated cell death in human melanoma cells: role of Bcl-2 expression. Oncogene 24: $178-187$ 